\title{
RISET IMPLEMENTASI PENGAJARAN TIGA PILAR GEREJA SUARA KEBENARAN INJIL MELALUI METODE EKSPLANATORI - KONFIRMATORI
}

\author{
Jos Sudarman Lauwanto \\ Sekolah Tinggi Teologi Ekumene Jakarta \\ Email: jos.sudarman@sttekumene.ac.id
}

Diterima tanggal: 24 Oktober 2020

Dipublikasikan tanggal: 27 Desember 2020

\begin{abstract}
ABSTRAK
Penelitian ini memiliki tujuan untuk mengetahui berapa besar implementasi pengajaran tiga pilar Gereja Suara Kebenaran Injil (disingkat GSKI), lalu dimensi apa yang dominan serta kategori latar belakang apa yang dominan dalam pengajaran tiga pilar tersebut. Metode yang peneliti gunakan adalah metode kuantitatif dengan pendekatan eksplanatori-konfirmatori. Peneliti mengajukan angket pernyataan kepada pejabat Gereja Suara Kebenaran Injil Jakarta. Berdasarkan hasil penelitian yang diperoleh ternyata besarnya implementasi pengajaran tiga pilar GSKI berada pada level tinggi, lalu dimensi yang dominan adalah tanggung jawab dan kategori latar belakang yang dominan adalah lama melayani dari pejabat gereja. Dengan hasil tersebut, maka rekomendasinya adalah untuk tetap mempertahankan level yang sudah tinggi dengan membuat modul pengajaran yang sistematis, mengadakan seminar tentang tiga pilar GSKI, mengadakan pertemuan rutin antara badan pengurus pusat dengan pejabat gereja, dan pemilihan calon pejabat secara selektif dan objektif.
\end{abstract}

Kata kunci: kesucian, langit baru, bumi baru, tanggung jawab, pilar gereja

\begin{abstract}
ABSTRACK
This research had a purposed was to determine how much the implementation of the teaching of the three pillars of the Bible's Truthful Voice Church (abbreviated as GSKI), then what dimensions are dominant and what background categories are dominant in the teaching of the three pillars. The method that researchers use is a quantitative method with an explanatoryconfirmatory approach. The researcher submitted a statement questionnaire to the officials of the Jakarta Gospel Truth's Church. Based on the research results obtained, it turns out that the magnitude of the implementation of the teaching of the three pillars of the GSKI is at a high level, then the dominant dimension is responsibility and the dominant background category is the length of service of church officials. With these results, the recommendation is to maintain a high level by making systematic teaching modules, holding seminars on the three pillars of the GSKI, holding regular meetings between the central board and church officials, and selecting candidates for officials selectively and objectively.
\end{abstract}

Keywords: holiness, new heaven, new earth, responsibility, church pillars 


\section{PENDAHULUAN}

Sebuah pengajaran dalam gereja adalah hal yang substansi dan mutlak dimiliki. Hal ini tentunya bukan sekedar syarat administratif belaka, namun juga memiliki dampak yang signifikan terhadap sebuah pertumbuhan gereja maupun iman jemaat. Pengajaran dari gereja memunyai tujuan agar murid mengenal Tuhan, sehingga mereka dapat percaya kepada-Nya dan hidup sesuai dengan firman-Nya.(Soeherman, 2003). Nova Ritonga mengatakan bahwa pengajaran yang dilakukan gereja seharusnya berpusat pada Allah (theosentris), dan teologi adalah sarana yang dapat digunakan dalam mempermudah untuk menjelaskan apa yang menjadi kehendak Allah atas umatNya.(Ritonga, 2020)

Saat berdirinya sinode baru yaitu Gereja Suara Kebenaran Injil atau disingkat GSKI pada tanggal 03 Desember 2018, maka persamaan pemahaman berkaitan dengan pengajaran menjadi sangat penting dan vital. Untuk itu dengan adanya pengajaran tiga pilar Gereja Suara Kebenaran Injil memiliki peran yang sangat penting dalam menjalankan semua aktivitas pelayanan yang ada di GSKI. GSKI Jakarta menjadi barometer dari seluruh perkembangan dan pertumbuhan kualitas baik secara jasmani terlebih lagi rohani dari seluruh pejabat gereja yang tersebar di seluruh 34 propinsi negara Indonesia maupun di luar negeri seperti di Sabah (Malaysia), Sidney, Notherdam, Amerika Serikat.

Peneliti melakukan wawancara dengan beberapa gembala jemaat dan pejabat gereja yang berada di wilayah Jakarta sekitarnya untuk mendapatkan informasiinformasi mengenai pengajaran tiga pilar GSKI ini sehingga di dalam penelitian ini mendapatkan gambaran secara komprehensif. Beberapa Gembala sidang yang berhasil peneliti lakukan wawancara antara lain Abraham Karel (gembala sidang GSKI Obor Kristus), Immanuel Keliat (gembala sidang GSKI Berea ), juga pejabat gereja di lingkungan GSKI yaitu Fredi Tiono (GSKI Rehobot Mall Artha Gading), James Wisan (GSKI Kebon Jeruk), Arfin Rahardja ( GSKI Mall Artha Gading), Rusdi Setiawan (GSKI Citicon pagi), dan Djoni Soebekthy (GSKI Citicon sore). Dari keterangan para pejabat gereja tersebut dapat diperoleh informasi bahwa modul atau diktat pengajaran tiga pilar GSKI perlu diadakan untuk memperjelas dan melengkapi pemahaman para pejabat gereja mengenai pengajaran tiga pilar GSKI ini. Memang pengajaran tiga pilar sudah diketahui oleh pejabat GSKI melalui pemberitaan Firman Tuhan baik di ibadah 
raya, ibadah Suara Kebenaran, Pendalaman Alkitab serta seminar-seminar yang rutin diadakan setiap bulannya, serta buku-buku karya Erastus Sabdono tetapi ini belum tersusun secara sistematis untuk mempermudah bagi pejabat GSKI dalam memahami pengajaran tiga pilar lebih mendalam.

Dari penelitian ini akan diperoleh informasi atau data-data yang menunjukkan tingkat implementasi pengajaran tiga pilar GSKI ini di kalangan pejabat GSKI Jakarta, variabel dimensi apa yang dominan dalam tiga pilar GSKI, dan latar belakang apa yang dominan dari pengajaran tiga pilar GSKI ini.

\section{METODE}

Metode penelitian yang dipergunakan dalam penelitian ini adalah penelitian kuantitatif dengan metode survei. Disebut survei karena penelitian ini menggunakan populasi langsung menjadi sampel yang representative untuk mengambil kesimpulan dengan menggunakan kuesioner atau angket sebagai pengumpulan data. Metode penelitian yang digunakan adalah survei yang bersifat eksplanatorikonfirmatori.(Prasetio \& Lina, 2008) Penelitian ini bersifat eksplanatori karena dalam proses penelitiannya ingin mengkaji/menggali secara mendalam variabel terikat (endogenous variable) yaitu pengajaran tiga pilar Gereja Suara Kebenaran Injil melalui pengembangan variabel bebas (exogenous variable) yaitu kesucian, langit baru dan bumi baru, dan tanggung jawab. Riset eksplanatori disini termasuk di dalam kategori kausal atau sering juga dinamakan kausal- komparatif.(Zaluchu, 2020) Responden penelitian adalah pejabat gereja di GSKI Jakarta yang berjumlah 171 orang. Data diperoleh dengan menyebar angket dengan model skala Likert.(Hasan, 2004) Data diolah dengan analisis Statistic Product and Service Solution (SPSS). Untuk mengetahui implementasi pengajaran tiga pilar GSKI mempergunakan analisis klas interval dengan kategori rendah, sedang, dan tinggi dengan memakai rentang angka lower-upper bound di setiap variabel. Untuk menghitung dimensi variabel yang dominan mempergunakan perhitungan uji signifikansi regresi (F reg).(Priyatno, 2010) Dan untuk menghitung kategori latar belakang yang dominan dalam pengajaran tiga pilar dengan menggunakan Classification and Regression Trees (CART) pada taraf signifikansi 0,05 dengan maximum trss depht $=2$, minimum cases in parent node $=2$, dan minimum cases in child note $=1$. Untuk menguji kategori latar belakang mana yang paling 
mempengaruhi variabel Y, akan dilakukan uji varian satu jalur (One way anova) pada taraf signifikansi 0,05 .

\section{HASIL DAN PEMBAHASAN}

\section{A. Tiga Pilar GSKI}

\section{Kesucian}

Menurut Kamus Besar Bahasa Indonesia istilah kesucian atau suci artinya kebersihan, kemurnian, bebas dari dosa, bebas dari cela.(Kemdikbud, 2020) Sesuai dengan definisi di atas maka kesucian adalah hidup besih, bebas dari dosa dan cela tanpa noda. Dalam bahasa Ibrani ada beberapa kata yang dalam Bahasa Indonesia dapat diterjemahkan sebagai suci atau kudus.(Sabdono, 2019b). Di antara kata-kata tersebut,

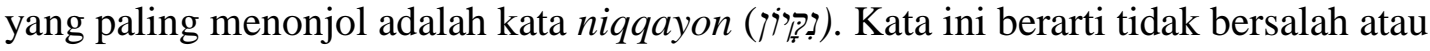
bebas dari hukuman dan bersih. Kata menguduskan, terjemahan bahasa Ibraninya adalah qadhash (קדָשָ). Kata sifatnya adalah qadhosh. Kata qadhosh itu bila dilihat dari etimologinya mengandung arti "dipisahkan dari yang lain untuk digunakan”. Jadi kata qadosh ini biasanya dipergunakan dalam wilayah ibadah kepada Yahwe atau berkenaan dengan pengampunan yang diberikan Allah kepada bangsa Israel.(Sabdono, 2019b) Dengan demikian dalam Perjanjian Lama, kata dikuduskan atau disucikan selalu dikaitkan dengan bangsa-bangsa, benda dan sebagainya maka hal itu selalu menunjuk kepada sesuatu yang dipisahkan dari yang lain atau sesuatu yang dikhususkan untuk digunakan oleh Allah.(Sabdono, 2019b) Dalam Perjanjian baru, orang-orang percaya dipanggil untuk menjauhkan diri dari cara-cara dunia dan nilai-nilai dunia, yang dapat menolak Allah dan merusak ketaatan kepada-Nya.(Themes, 2009) Kata "kudus" dalam bahasa Yunani ada beberapa pengertian, terdapat kata $\dot{\alpha} \gamma l \dot{\alpha} \zeta \omega$ (hagiazō), kata kerja yang berarti menguduskan, mempersucikan, menjadikan kudus, menganggap suci, memperlakukan sebagai kudus. Dapat juga merujuk pada sikap hormat manusia yang ditunjukkan pada hal ilahi.(Mangum, 2014) Selain kata hagiazo, juga ada kata katharoi ( $\kappa \alpha \theta \alpha \rho o i)$ berarti suci (clean), yang terdapat dalam Matius 5:8 yang tertulis "Berbahagialah orang yang suci hatinya, karena mereka akan melihat Allah". Kata suci di sini mengandung pengertian free from impure admixture, without blemish, spotless (bebas dari dari campuran, tidak bernoda). (Sabdono,2019b) Ada juga kata hagios

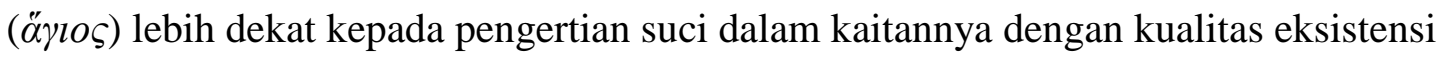
Allah.(Mangum, 2014) Kalau kata suci ini dikenakan dalam hidup orang percaya, maka 
hal ini menunjukkan perbedaan yang absolut antara orang percaya dan orang yang tidak percaya. Lalu untuk kata katharoi lebih menunjuk kepada keadaan hati yang tidak ternodai oleh pengaruh dunia sekitar. Sedangkan kata hagios yang sejajar dengan kata hieros, hosios dan hagnos yang penggunaannya berkenaan dengan karya Tuhan Yesus di kayu salib dalam menyelamatkan umat manusia yang percaya kepada-Nya.(Mangum, 2014) Kata hagios ini dalam Bahasa Latin diterjemahkan menjadi sanctifikatio, kemudian dalam bahasa Inggris diterjemahkan sanctification, dan dalam Bahasa Indonesia menjadi sanktifikasi, yang artinya sama dengan pengudusan atau penyucian.(Sabdono,2019b).

Manusia adalah makhluk hidup yang memiliki tanggung jawab untuk menjalani hidup ini dengan kehendak bebas dimana harus memilih hidup dalam kesucian selama masih menumpang di dunia ini. Manusia sudah ditebus oleh Yesus dengan darah-Nya sehingga ini membuat manusia harus mentaati apa yang diperintahkan-Nya. Kesucian hidup merupakan buah pertobatan, dimana seseorang harus memisahkan dirinya untuk kepentingan Allah sehingga ia dipakai oleh Allah.(Pardede, 2019)

Rasul Petrus menulis surat yang terdapat pada 1 Petrus 1:15: "Tetapi hendaklah kamu menjadi kudus di dalam seluruh hidupmu sama seperti Dia yang kudus, yang telah memanggil kamu." Nilai utama dari surat ini adalah bagaimana orang percaya harus hidup dalam kekudusan sama seperti Yesus yang hidup dalam kekudusan. Kata kudus dalam bahasa aslinya $\alpha$ zıoৎ (hagios) artinya hal yang paling suci, kesucian bukan hanya berarti bersih dari noda. Kesucian juga menunjuk kepada integritas diri yang kokoh tidak terhanyut oleh pengaruh pola hidup yang tidak sesuai dengan kehendak Allah, walaupun hidup di tengah-tengah masyarakat dunia yang rusak ini.(sproul, 2009) Dedikasi orang percaya kepada Yesus Kristus dan iman Kristen ditunjukkan dalam kehidupan spiritual yang murni atau suci.(Setio, 2012) Manusia yang sudah jatuh dalam dosa tidak bisa mencapai standar kesucian Allah, karena mereka sudah kehilangan kemuliaan Allah. (Sabdono, 2019b) Karya keselamatan di dalam Yesus Kristus menyediakan fasilitas keselamatan, yaitu penebusan, Injil, Roh Kudus dan penggarapan. Dari Roh Kudus inilah yang memimpin manusia dalam proses pembaharuan pikiran. Jadi, betapa pentingnya pengajaran tentang kesucian yang harus disampaikan kepada jemaat karena tanpa kesucian tidak seorang pun dapat melihat Allah (Ibrani 12:14). Tidak mungkin orang bisa mengalami kekudusan yang benar tanpa 
Firman Tuhan. Firman Tuhan memperbaharui pikiran seseorang atau cara berpikir seseorang.

Melalui korban penebusan Tuhan Yesus menempatkan manusia yang telah berdosa dianggap sebagai manusia yang tidak berdosa, sebab semua dosa yang sudah dilakukan, sedang dilakukan dan yang akan nanti sudah dipikul oleh Yesus di kayu salib (Sabdono,2019b). Pengudusan ini belum membuat seseorang benar benar baik. Inilah pengudusan atau penyucian pasif. Penyucian pasif ini adalah perubahan status dan sekaligus membuka kemungkinan yang nantinya melalui proses pendewasaan manusia menjadi suci seperti Allah. Ini sesuai apa yang di tulis dalam Injil Matius 5:48 bahwa: “ Karena itu haruslah kamu sempurna, sama seperti Bapamu yang di sorga adalah sempurna."(Sabdono,2019b). Jadi, umat percaya harus berjuang sungguh-sunguh untuk berkeadaan benar-benar suci. Kalau tidak benar-benar suci maka pengudusan secara pasif atau pembenaran dari Tuhan Yesus menjadi sia-sia atau batal (Sabdono,2019b).

Orang Kristen yang tidak berani mengenakan hidup suci berarti mereka tidak percaya kepada Tuhan Yesus. (Sabdono,2019b).

\section{Langit Baru dan Bumi Yang Baru}

Langit baru dan bumi yang baru ini, sama dengan surga. Kata "surga" dalam terjemahan Bahasa Ibrani adalah (shamayim). Kata ini berbentuk jamak dari bentuk tunggalnya (shameh) yang artinya langit. Pada umumnya kata ini selalu ditulis jamak, hal tersebut bisa menunjukkan bahwa jagad raya ini luas terdiri dari berbagai tingkatan langit dan bintang-bintang.(Sabdono, 2019d) Dalam bahasa Yunani, kata "surga" adalah ov̉ $\alpha v o ́ \varsigma$ (ouranos) dengan pengertian yang sama dengan shamayim. Sedangkan dalam bahasa Inggris lebih sering ditulis dengan kata heaven, dari pada kata sky (langit yang melingkupi bumi).(Sabdono, 2019c) Menurut Billy Graham, mengenai surga adalah tempat yang ada secara harfiah. Surga bukanlah dunia fantasi atau negeri khayalan.(Graham, 2015) Karena Allah menciptakan surga dengan segala karakteristik yang autentik. Yesus tidak naik ke dunia mimpi yang tinggi setelah kebangkitan-Nya, tetapi kembali duduk di sebelah kanan Allah.(Graham, 2015) Menurut Sabdono bahwa surga adalah suatu alam bersifat fisik, sebab surga adalah kelanjutan dari sejarah alam semesta secara fisik ini, alam semesta yang diciptakan 
Tuhan dengan segala fasilitasnya yang dapat dinikmati oleh seluruh tubuh kebangkitan.(Sabdono, 2019d)

Tuhan Yesus menyatakan kepada orang percaya bahwa mereka jangan gelisah dan menaruh percaya kepada-Nya bahwa Dia pergi menyediakan tempat bagi orang percaya dan pada saatnya nanti Dia akan datang kembali untuk membawa umat-Nya ke tempat di mana Dia berada (Yohanes. 14:1-3).

Umat kristen selalu diingatkan bahwa dunia ini bukan tempat tinggal selamanya hanya tempat tinggal sementara dan ini akan segera berlalu sehingga umat kristen harus memanfaatkan kehidupan di dunia yang fana ini untuk mempersiapkan diri sebaikbaiknya untuk memasuki kerajaan Surga. Kerajaan Surga adalah tempat khusus di mana hanya orang-orang pilihan yang boleh masuk.(Sabdono, 2019d)

Ryle menulis bahwa petualangan terbesar, yang tidak akan pernah berakhir, akan mendiami dan menjelajahi bersama untuk kemuliaan Kristus, bumi baru dan langit baru. (J.C, 2000) Inilah pengharapan sesungguhnya yang dimiliki umat Kristen yaitu langit baru dan bumi yang baru.

\section{Tanggung Jawab}

Tanggung jawab merupakan bagian dalam kehidupan manusia, artinya setiap manusia pasti dibebani tanggung jawab. Tanggung jawab menjadi ciri manusia yang beradab atau berbudaya karena ia menyadari akibat baik atau buruk dari perbuatannya itu, dan menyadari pula bahwa pihak lain memerlukan pengabdian atau pengorbanannya. Menurut KBBI, kata tanggung jawab adalah suatu keadaan dimana wajib menanggung segala sesuatunya (kalau terjadi apa-apa boleh dituntut, dipersalahkan, diperkarakan, dan sebagainya) sehingga berkewajiban menanggung, memikul jawab, menanggung segala sesuatunya atau memberikan jawab dan menanggung akibatnya.(Kemdikbud, 2020) Tanggung jawab yang dimaksud dalam tiga pilar ini adalah orang percaya bertanggung jawab atas apa yang Tuhan sudah percayakan dalam hidupnya. Tuhan tidak melihat berapa banyak talenta yang sudah diberikan Tuhan kepada manusia, tetapi Tuhan melihat pertanggung jawaban atas apa yang sudah dipercayakan-Nya kepada manusia.

Dalam tanggung jawab terkandung pengertian penyebab dari apa yang dialami manusia. Orang bertanggung jawab atas sesuatu yang disebabkan oleh keputusan dari 
tindakannya.(Sabdono, 2019a) Ini sejalan apa yang di tulis di surat Roma 14:12 yaitu bahwa setiap orang akan memberi pertanggungan jawab tentang dirinya sendiri kepada Allah.

Setiap orang percaya masing-masing mendapat kesempatan yang berbeda, tetapi seberapa Tuhan berikan harus dimanfaatkan dengan sungguh-sungguh. Kalau fasilitas yang Tuhan sediakan tidak digunakan secara bertanggung jawab, maka kesempatan ini akan hilang dan tidak ditemukan lagi. (Sabdono,2017b)

B. Data Penelitian

1. Berdasarkan tabel interval yang dibuat dan posisi Kecenderungan Implementasi pengajaran tiga pilar Gereja Suara Kebenaran Injil di kalangan pejabat Gereja Suara Kebenaran Injil Jakarta, sebagai berikut:

\begin{tabular}{|l|l|l|}
\hline Interval & Kategori & Nilai lower dan Upper Bound variabel Y \\
\hline $114-129$ & Rendah & \\
\hline $130-145$ & Sedang & \\
\hline $146-161$ & Tinggi & $153.0022-155.8063$ (Tinggi) \\
\hline
\end{tabular}

2. Dari perhitungan sumbangan kontribusi setiap dimensi exogenous terhadap endogenous variabel maka dapat direkap menjadi tabel sebagai berikut :

\begin{tabular}{|l|l|l|l|lr|}
\hline No & Dimensi & R & r square & \multicolumn{2}{|l|}{ Kontribusi } \\
\hline 1 & Kesucian & 0,559 & 0,312 & 31,2 & $\%$ \\
\hline 2 & Langit Baru dan Bumi Baru & 0,812 & 0,660 & 66 & $\%$ \\
\hline 3 & Tanggung Jawab & 0,857 & 0,734 & 73.5 & $\%$ \\
\hline
\end{tabular}

3. Dari hasil analisis antara exogenous variable latar belakang sampel secara bersama-sama terhadap endogenous variable menunjukkan bahwa latar belakang Latar belakang Lama Melayani mampu memperbaiki sebesar 0.841 kali dari kondisi Implementasi pengajaran tiga pilar GSKI di kalangan pejabat Gereja Suara Kebenaran Injil Jakarta (Y) yang sekarang secara signifikan pada $\alpha<0,05$ serta Latar belakang Lama Melayani $\left(\mathrm{L}_{5}\right)$ memiliki 
tingkat importansi/sanggup mempengaruhi 100\% derajad distribusi perolehan skor Implementasi pengajaran tiga pilar GSKI sebesar 3.891

Independent Variable Importance
\begin{tabular}{|l|l|l|}
\hline Independent Variable & Importance & $\begin{array}{l}\text { Normalized } \\
\text { Importance }\end{array}$ \\
\hline Lama_Melayani & 3.891 & $100.0 \%$ \\
Usia & 3.112 & $80.0 \%$ \\
Status & 1.244 & $32.0 \%$ \\
Pendidikan & .163 & $4.2 \%$ \\
Jenis_Kelamin & .084 & $2.1 \%$ \\
\hline
\end{tabular}

\section{Analisis Hasil}

1. Implementasi pengajaran tiga pilar GSKI berada pada level tinggi

2. Dimensi tiga pilar GSKI yang dominan adalah tanggung jawab

3. Kategori latar belakang implementasi pengajaran tiga pilar GSKI yang dominan adalah latar belakang lama melayani.

\section{SIMPULAN}

Berdasarkan hasil penelitian yang diperoleh bahwa implementasi pengajaran tiga pilar GSKI berada pada kategori tinggi, dan dimensi yang dominan adalah tanggung jawab, sedangkan kategori latar belakang yang dominan adalah lama melayani. Dan untuk mempertahankan implementasi pengajaran tiga pilar GSKI pada level tinggi ini maka modul untuk tiga pilar GSKI perlu dibuat sebagai pedoman bagi setiap pejabat gereja. Dan dengan perkembangan teknologi 4.0 maka modul tiga pilar GSKI ini dapat diakses oleh semua pejabat GSKI di manapun berada. Dengan demikian, modul pengajaran tiga pilar ini akan memperjelas, bahkan melengkapi apa yang sudah diterima oleh setiap pejabat GSKI. Dalam mempertahankan kondisi implementasi pengajaran tiga pilar yang tinggi ini, bukan hanya menjadi tanggung jawab dari ketua sinode GSKI tetapi semua pejabat gereja baik yang berada di level Badan Pimpinan Pusat, gembala wilayah maupun semua pejabat gereja yang ada dalam mempertahankan implementasi pengajaran tiga pilar GSKI tetap pada level tinggi. Adapun tiga pilar nilai kehidupan GSKI adalah Pertama, Kesucian. Nilai atau pengajaran difokuskan pada kekudusan hidup dan pemulihan karakter sesuai dengan rancangan Allah semula yaitu seperti 
Kristus. Karena manusia sudah ditebus oleh Yesus dengan darah-Nya sehingga ini membuat manusia harus mentaati apa yang diperintahkan-Nya. Rasul Petrus menulis surat yang terdapat dalam 1 Petrus 1:15: "Tetapi hendaklah kamu menjadi kudus di dalam seluruh hidupmu sama seperti Dia yang kudus, yang telah memanggil kamu.” Nilai utama dari surat ini adalah bagaimana orang percaya harus hidup kudus sebab sama seperti Yesus yang kudus. Kedua, Langit Baru dan Bumi Baru (2 Petrus 3:13: "Tetapi sesuai janji-Nya, kita menantikan langit yang baru dan bumi yang baru, di mana terdapat kebenaran“). Jadi, pengertian langit baru dan bumi yang baru itu menunjuk kepada surga. Ketiga, Tanggung Jawab. Hal ini hendak menjelaskan tentang talenta yang telah diberikan oleh Tuhan kepada manusia harus dipertanggung jawabkan. Manusia harus bertanggung jawab setiap talenta atau potensi yang sudah diberikan oleh Tuhan untuk dikembangkan yang pada akhirnya semuanya itu untuk kemuliaan Allah. Allah tidak melihat sedikit banyak talenta yang dimiliki setiap individu, tetapi Allah melihat apakah setiap individu itu bertanggung jawab atas apa yang mereka sudah terima dari-Nya? Pengajaran tiga pilar GSKI ini memang sudah disampaikan oleh penggagas dari tiga pilar ini yaitu Erastus Sabdono, sekaligus ketua umum dari sinode GSKI tetapi belum adanya modul atau diktat pengajaran tiga pilar GSKI secara sistematis dapat mempengaruhi dalam mengimplementasikan pengajaran tiga pilar ini. Keterbatasan penelitian ini hanya dilakukan pada kalangan pejabat GSKI Jakarta saja, dan sebaiknya dilakukan kepada seluruh pejabat GSKI yang ada sehingga keakurasiannya akan jauh lebih baik. Dan untuk itu, rekomendasi dari penelitian ini adalah melanjutkan penelitian ini sampai ke seluruh pejabat GSKI yang ada di luar Jakarta hingga di luar negeri agar dapat mengetahui tingkat implementasi pengajaran tiga pilar GSKI ini pada keseluruhan pejabat GSKI.

\section{DAFTAR PUSTAKA}

Graham, B. (2015). The Heaven Answer Book. Yogyakarta: ANDI Offset, Yokyakarta. Hasan, I. (2004). Analisis Data Penelitian dengan Statistik. Jakarta: Bumi Aksara. J.C, R. (2000). Heaven. (Rossshire: Christian Focus Publications.

Kemdikbud. (2020). KBBI. Retrieved from https://kbbi.kemdikbud.go.id/entri/nurani Mangum, D. (2014). Holiness, Lexham Theological Wordbook, Lexham Bible Reference Series. Bellingham, WA: Lexham Press. 
Pardede, Z. (2019). Rancang Bangun Teologi “Kekudusan” Tentang Hamba Tuhan Sebagai Pemimpin Kristen Menurut Kitab Yosua. KHARISMATA: Jurnal Teologi Pantekosta. https://doi.org/10.47167/kharis.v1i2.20

Prasetio, B. dan J., \& Lina, M. (2008). Metode Penelitian Kuantitatif. Jakarta: Raja Grafindo Persada.

Priyatno, D. (2010). Paham analisis statistik data dengan SPSS. MediaKom.

Ritonga, N. (2020). Teologi Sebagai Landasan Bagi Gereja dalam Mengembangkan Pendidikan Agama Kristen. Jurnal Shanan, 4(1), 21-40. Retrieved from http://ejournal.uki.ac.id/index.php/shan/article/view/1766

Sabdono, E. (2019a). Anthroplogy (Rehobot Literature. Jakarta: Rehobot Literature.

Sabdono, E. (2019b). Mencapai Kesucian. Jakarta: Rehobot Literature.

Sabdono, E. (2019c). New Paradigm of Christian Living. Jakarta: Rehobot Literature.

Sabdono, E. (2019d). Surga. Jakarta: Rehobot Literature.

Setio, R. (2012). Isu-isu Pendidikan Teologi di Indonesia.

Soeherman, S. (2003). Tujuan Pengajaran Gereja dan Implikasinya. Veritas : Jurnal Teologi Dan Pelayanan, 4(1), 107-119. https://doi.org/10.36421/veritas.v4i1.101 sproul, R. (2009). Defending Your Faith: An Introduction to Apologetics. wheaton: crossway.

Themes, H. M. (2009). The Accessible and Comprehensive Tool for Topical Studies. London: Martin Manser.

Zaluchu, S. E. (2020). Strategi Penelitian Kualitatif dan Kuantitatif Di Dalam Penelitian Agama. Evangelikal: Jurnal Teologi Injili Dan Pembinaan Warga Jemaat, 4(1), 28. https://doi.org/10.46445/ejti.v4i1.167 